\title{
Organizational Learning as a Strategic Choice in Public aße Sector Organization: Changing Cultural Attributes in a State Owned Agricultural Bank of Bangladesh
}

\author{
Md. Ali Ahsan \\ PhD Candidate, Department of Human Resource Development, Faculty of Cognitive Sciences and Human Development, Universiti Malaysia \\ Sarawak, Sarawak, MALAYSIA \\ E-mail for correspondence: aliahsan.rubd@gmail.com
}

No Conflict of Interest: Declared

\begin{abstract}
Network governance has become an important paradigm in recent reform effort; inter-sectoral collaboration is the key theme of such initiative. As part of the developing world, Government of Bangladesh is taking initiatives to prepare its civil service competent to meet the challenges of a welfare state for a sustainable society. Taking this in an account, this study focuses on the recent reform program in public sector organization initiated by the government. The core objective of this study is to understand the phenomenon of organizational culture that has an influence on organizational learning and innovation from the viewpoint of experienced civil servants who have gone through the change process and become an active implementer of learning and innovation in their organization to meet the desire change situation.
\end{abstract}

Keywords: Organizational Learning, Strategy, Organizational Reform, Public Sector Organization

\section{INTRODUCTION}

Organizational behavior of the members in organization is highly influenced by its culture and work ethics, which is practiced in everyday's work. It shapes the sense-making mechanism within the organization that actually persuade the organizational manner, thus contributing to the development of shared understanding (Tian, Deng, Zhang, \& Salmador, 2018; Bierly, Kessler, \& Christensen, 2000). Culture, in turn, is shaped by the organization's structure (Friesl, Sackmann, \& Kremser, 2011). Thus the likelihood that an organization's culture will be supportive of organizational learning (hereinafter referred to as " $\mathrm{OL}^{\prime}$ ) is enhanced if liberating structures, which overcome learning barriers and empower employees to challenge conventional wisdom amongst other freedoms, are in place (Kolodinsky, \& Bierly, 2013; Bierly et al., 2000).

To the contrary, a culture that may impede OL is likely to be one where risk-taking, openness in communication and teamwork are not valued (Moon, \& Lee, 2015; JerezGomez, Cespedes-Lorente, \& Valle-Cabrera, 2005; Coulson-Thomas, 2003). A culture where these characteristics are present has been proclaimed as essential for crafting a learning strategy (Slocum, McGill, \& Lei, 1994), with some authors maintaining that learning requires a culture open to new ideas, innovation and a high degree of experimentation (Jerez-Gomez et al., 2005; Chan, \& Scott-Ladd, 2004) and positive notion towards change (Michalak, 2010; Coulson-Thomas, 2003) and which is also blame-free (Yeo, 2007a). OL can therefore be facilitated by ensuring the presence of enabling features of the structure and culture of an organization.

In this juncture, it is imperative to study the influential organizational culture on OL in public sector organization. Although in general the main thrust of OL research has been directed to business organization, in last fifteen years' public sector organizations are also received attention to this matter (Gilardi, \& Radaelli, 2012; Maden, 2012; Rashman, Withers, \& Hartley, 2009). Following the trends of 'New Public Management'; 'E-Government' and 'Reinventing Government'; public sector organizations are facing the incremental public and political pressure to their service delivery. It is also become imperative to become more transparent and accountable in their administrative processes (Gilson, Dunleavy, \& Tinkler, 2009; Dent, Gestel, \& Teelken, 2007; Mouritsen, Thorbjørnsen, Bukh, \& Johansen, 2004). To achieve this, OL is increasingly considered as a significant requirement in public sector organizations (Greiling, \& Halachmi, 2013; Bovens, Schillemans, \& Hart, 2008; Schofield, \& Sausman, 2004; Betts, \& Holden, 2003; Brown, \& Brudney, 2003). 
Predominantly, from the viewpoint of a developing country like Bangladesh, where public sector reform is taking place in a rapid manner (Tahrima, \& Jaegal, 2012).

\section{Changing Cultural Attributes on Organizational Learning in Public Sector ORGANIZATION}

Since 1970 many governments have engaged in reform processes aimed at bringing business concepts, techniques, and values into the public sector. This movement has been termed New Public Management (NPM) and often resulted in major shifts in accounting, budgeting, and performance measurement systems as a basis for better management and more appropriate accountability. Precisely, governments have become more networked than ever before. Crosssectoral collaboration has become a new trend in public sector organizations. As governments entering the digital age, public sector organizations are becoming more technology savvy. Government organizations are becoming more open towards the people so that they can become peoples' organization. Service innovation and learning have become the buzzword for public sector organizations.

In the digital era, it is imperative to become more networked to become more engaged in public service. So, public sector organizations can face the challenges of recent change that are happening dramatically. Collaboration with stakeholders is one of the crucial factors to become more peoples friendly. Public sector organizations need to understand the emerging demand of the people. Inter-sectoral collaboration is also regarded as one of the significant aspects of the government. When learning is the only option to survive and sustain for the future, then it is better to engage with the other sector to enhance knowledge through practical experiences along with the partners from the different sector. Specifically, public sector organizations need to be more open towards networking to bring out the best for the society.

Several initiatives has been taken by the Government of Bangladesh to nurture innovation through learning in the public sector organizations i.e., incorporation of Governance Innovation Unit (GIU) in 2016 was one of the landmark step in the field of knowledge-based innovative public service in the history of Bangladesh. Through this initiative the government introduced a benchmark for the goal-oriented and performance-based civil service in the country. Under this innovation program government incorporated access to information, citizen charter, ICT based public service delivery, Public-Private Partnership (PPP). This kind of initiatives brought changes among the public servant's conventional mindset about service delivery. This study found that the socio-cultural viewpoint of the public servants has been changed and they have the opportunity to think out of the box towards sustainable development.

\section{Methods}

This research employs phenomenology as the main research method to understand and explore the reality of the case.

\section{Study Area and Informants}

The study is based on case study method. A single public sector organization is chosen for the study. Particularly the mid-level management was the targeted population of the study considering the strategic role in OL and innovation during the period of change. Most of the informant has diversified experience in the organization and focused on recent innovation initiatives by the government.

The precise interview guide constructed on the basis of several previous guidelines so that; informants can contribute rich data from their phenomenological organizational set-up. Thus, the researcher make a deliberate atmosphere during interview session, so that informants can describe the real scenario but with the focus on a particular subject that has been predetermined.

\section{Ethical Issues}

Ethical conduct is a set of moral principles and values that guide the researcher while conducting research activities (Ahmad, \& Hasbee, 2011). Punch (1994) as cited in Ntseane (2009, p. 296), suggested that ethical issues in research encompass of protecting the right of individual privacy, an informed consent, voluntary participation, and confidentiality and anonymity of the informants. Therefore, before the interview process, the researcher informed the informants were well-aware on the purpose of the study. Once the informants agreed to participate, they were enquired to sign informed consent form that indicates they understood the purpose of the study, their right as informants of the study and they agreed to participate in the study.

\section{FINDINGS AND DISCUSSION}

This study finds some of the significant issues related to OL in public sector organization, particularly during the period of change in government. Based on the empirical findings the researcher describes the result in support of previous evidence.

\section{Shared Understanding}

Shared understanding is regarded as the most important influential factor for OL. Informants of the study emphasized on organizations systematic organic structure where people interact under some specific objectives to achieve (Andreadis, 2009; Yeo, 2007b; Gummesson, 2006; Jerez-Gomez, Cespedes-Lorente, \& Valle-Cabrera, 2004). Working for the same objective makes them more interactive and interdependent of their understanding and behavior, so that they can share their ideas and new knowledge. Informants stress on shared understanding to achieve organizational goals collectively through sharing new ideas and, knowledge gathered form training and learning session organized by the organization (Fenwick, 2008; Tynjala, 2008; Espinosa, Harnden, \& Walker, 2007; Choo, 2001; Bierly \& Hämäläinen, 1995). 
Likewise, informants stated that networking always creates opportunities for new kind of learning to manage new kind of situation emerges in organizational life and help to reflect on desired outcomes. For fruitful networking, there must be a good understanding among the employees so that they can share their ideas in a free manner. It may regard as the social process of collaboration. Now-a-day the public service modernize as there are several reform initiatives has been taken, these initiatives make public organization more learning oriented towards innovation (Espinosa, \& Porter, 2011; Fenwick, 2008; Espinosa et al., 2007; Chanal, 2004). Moreover, key informants comply with the previous statement and vow shared understanding as a competiveness for the organizational change management process (Popova-Nowak, \& Cseh, 2015; Bierly et. al., 1995). So, shared understanding play a very crucial role in OL process, as it is like a physiological bonding among the employees who are working together under an organizational mission (Putz, Schilling, Kluge, \& Stangenberg, 2012; Kluge, \& Schilling, 2009).

\section{Vision and Leadership Approach}

The evidence comes from findings of this study provide that leadership and OL have significant positive relationship influence on organizational vision. The research also demonstrates that there is a significant effect on the role of mediation in OL on the relationship between leadership and organizational vision (Kamya, 2012; Hoe, 2007; Yeo, 2007a; Hodgkinson, 2002). Key informants stated that capable leadership could foster OL towards building a shared organizational vision through coping with organizational changes. Informants reinforces this statement by adding new dimension of leadership can establish confidence among the employees by instilling suitable atmosphere for learning (Kurland, Peretz, \& Hertz-Lazarowitz, 2010; Hodgkinson, 2002; Silins, Mulford, \& Zarins, 2002; Bierly et al., 2000; Senge, Kleiner, Roberts, Ross, \& Smith, 1999). Informants also emphasizes on leadership sense-making capability that can infuse employees' adaptability towards a new dimension of work by focusing more on organizational vision and learning (Voronov, 2008).

Informants share the experience that, leaders can fabricate trust and confidence among the employees to be a better learner in the workplace. One key informant added that, as a subordinate they have great expectation form their leader to transformation in nature who can nurture their individual and organization goals in a similar vein (Chen, Zheng, Yang, \& Bai, 2016; Hsiao, \& Chang, 2011; Garcia-Morales, MatiasReche, \& Hurtado-Torres, 2008; LeBrasseur, Whissell, \& Ojha, 2002; Bierly et al., 2000). Likewise, informants were also appreciate organizational leadership for playing a crucial role in OL which can create an atmosphere of organizational addictiveness to cope with the new situation and also are in-line with the organizational vision (Liao, Chen, Hu, Chung, \& Liu, 2017; Mirkamali, Thani, \& Alami, 2011; Atwood, Mora, \& Kaplan, 2010; Berson, Shamir, Avolio, \& Popper, 2001). In this research, most of the informant shows trust in their leadership which makes them confident to establish a shared vision through OL.

\section{Decision-Making Pattern}

Decision-making process is a crucial activity in organizations. Making decision is one of the core responsibilities for the managers in every level of the organization to run it in proper manner. This systematic approach is dissimilar depending on three tips: managerial level, importance of decision, and decision making styles. The styles of decision making is the most critical one because it reflects the mentality or the way of thinking of managers in organizations (Johannessen, \& Olsen, 2011; Willema, \& Buelens, 2009). Moreover, it explains how the managers use information and how they conceptualize and envision the future of their organizations (Choo, \& Neto, 2010). Informants mentioned that decision-making styles affect knowledge acquisition, sharing, and utilization (Espinosa et al., 2007; Choo, 2001). Choo (2001) also argued that success in the innovative programs and learning depends on the styles of decision making processes.

Hence, decision-making pattern is all about sense-making and sense giving process where cognitive style controls their behavior. Informants were also mentioned that decision-making pattern is influenced by sense-making and sense giving process (Ghili, Nazarian, Tavana, Keyvanshokouhi, \& Isaai, 2013; Bustinza, Molina, \& AriasAranda, 2010). So, decision-making pattern is a matter of human cognition, though it is shaped by the organizational environment and mostly by previous experience. OL and decision making pattern precisely interdependent matter, both have a mutual influence on each other (Espinosa, \& Porter, 2011; Snowden, 2005). Decision making pattern is the exploration of the mental model of human being that actually shapes the organizational culture of the organization in an individual and collective manner (Sánchez, Vijande, \& Gutiérrez, 2009; Jensen, \& Rasmussen, 2004; Senge et al., 1999).

\section{Human Resource Development}

The primary developmental role of OL is played by individuals, since the organization would not exist without them. Therefore, human resource development may contribute to the capacity of the organization to learn, by facilitating the development of organization-specific competencies that result in complex social relationships based on the organizations history and culture (Werner, \& DeSimone, 2012). Human resource development practitioners take the lead to transfer individuals' OL to their job performance by designing appropriate human resource development activities (Keep, 2015; Lim, \& Morris, 2006). Informants stressed on human resource development as a strategic imperative in the rapidly changing public sector organization. As a part of organizational culture human resource development influence OL process by its nature and extent, this is supported by key informants of the study. 
By influencing OL culture, human resource development has a great impact on informal learning capability of the organization and elimination of misconception of information among the employees (Armstrong, \& Taylor, 2014). In a similar vein, informants also asserted that human resource development is one of the key factors for OL. It helps employees to understand the importance of OL and how OL can enhance their career towards better organizational performance. Human resource development also brings out the positive learning culture within organization, which may eliminate the misconception about change process and it creates a vision of fruitful learning (Wang, Lamond, \& Worm, 2015; Harrison, \& Kessels, 2004; Ter Horst, Mulder, Sambrook, Scheerens, Stewart, \& Tjepkema, 2003). Human resource development also shapes the learning capability in organizational structure by preparing entailed infrastructure, network, and system (Garavan, \& McCarthy, 2008). So, human resource development regarded as one of the most important elements that influence OL within the public sector organization as part of organizational structure and culture. As the central idea of human resource development is to find out the best organizational culture, which is more suitable for learning and development. Thus, the organization can obtain strategic advantages of human capital for a sustainable future (Beattie, Kim, Hagen, Egan, Ellinger, \& Hamlin, 2014; Schechter, \& Atarchi, 2014; Beattie, 2006).

\section{Organizational Power and Politics}

Acquisition of new knowledge is always associated with different interests from a variety of actors. The learning processes are to a large extent governed by political ideology, prescribing what is the valuable learning and what is not (Cacciattolo, 2015; Sánchez, Vijande, \& Gutiérrez, 2010; Lawrence, Mauws, Dyck, \& Kleysen, 2005). Key informants mentioned that in public sector organization it is an imperative to have comprehensive knowledge of power and political issues, as some extent public sector organizations are the part of the socio-political system of the country. Power and politics are also the part of the cultural structure of the society, which shapes inter and intra-organizational knowledge within the organization. OL is an embedded part of this organizational life, so OL is shaped by the organizational politics and power as per its public nature (Ege, Esen, \& Dizdar, 2017; Nonaka, \& Krogh, 2009; Ferdinand, 2004; Coopey, \& Burgoyne, 2000).

Moreover, when things go wrong in the public domain, organizations often face increased political involvement and demands to improve. This situation creates learning imperative within the organization. As source of information, lesson-drawing, knowledge dissemination and institutionalization process is facilitated by organizational power-politics. It may encourage the employee to share diversified knowledge among the employees (Lawrence, Mauws, Dyck, \& Kleysen, 2005; Coopey, \& Burgoyne, 2000; Nonaka, \& Takeuchi, 1995; Levitt, \& March, 1988).
Eventually, informants added that, when things in the public domain go wrong, government bureaucracies usually face increased political scrutiny and strong demands for reform. The need for OL is high under such circumstances (Dekker, \& Hansen, 2004). As public organizations core focus on public service, it is imperative to emphasize on public interest and demand on time. Power and political structure allow them to learn about situation.

Although studies of OL have conceptualized it primarily as a social-cognitive process, it is also an inherently political one. Several public administration researchers argue that power and politics provide the social energy that transforms the insights of individuals and groups into the institutions of an organization. Moreover, they propose that different forms of power in organizations are connected to specific learning processes - intuition is linked with discipline, interpretation with influence, integration with force, and institutionalization with domination - and that an examination of these different forms of power provides a basis for understanding why some insights become institutionalized while others fail to do so. Thus, the discussion of OL process in public sector organization is profoundly embedded its power-politics culture, which is an identical part of public sector organizations (Dekker, \& Hansen, 2004). Moreover, informants of this study assert that taking strategy as an integral part of OL that can improve innovation capability towards sustainable development. They also mentioned accountability is an influential factor in OL process, due to the public perspective on public sector organization.

\section{CONCLUSIONS}

This study reveals some of the significant cultural issues that have the influence on OL in public sector organization, from the viewpoint of a developing country like Bangladesh. It also bridges the gap between organizational culture and OL process in a bureaucratic setup, which may bring new insights for the future researchers in this field. Last but not least current study opens a new horizon of thought about OL from Bangladeshi context, and this may regard as the initiative to conduct further research. Eventually, this study will contribute to the paradigm of Public Administration in South-Asian context from the cognitive and behavioral aspect of the organization.

\section{REFERENCES}

Ahmed, R., \& Usop, H. (2011). Conducting research in social sciences, humanities, economics and management studies: A practical guide. RS Group Publishing House, Kuching, Malaysia.

Andreadis, N. (2009). Learning and organizational effectiveness: A systems perspective, Performance Improvement, 48(1), 5-16.

Armstrong, M., \& Taylor, S. (2014). Armstrong's handbook of human resource management practice. Kogan Page Publishers, London.

Atwood, M. A., Mora, J. W., \& Kaplan, A. W. (2010). Learning to lead: evaluating leadership and organizational learning. Leadership \& Organization Development Journal, 31(7), 576-595. 
Beattie, R. (2006). Line managers and workplace learning: learning from the voluntary sector. Human Resource Development International, 9(1), 99-119.

Beattie, R. S., Kim, S., Hagen, M. S., Egan, T. M., Ellinger, A. D., \& Hamlin, R. G. (2014). Managerial coaching: A review of the empirical literature and development of a model to guide future practice. Advances in Developing Human Resources, 16(2), 184-201.

Berson, Y., Shamir, B., Avolio, B. J., \& Popper, M. (2001). The relationship between vision, strength, leadership style and context. The Leadership Quarterly, 12(1), 53-73.

Betts, J., \& Holden, R. (2003). Organizational learning in a public sector organization: a case study in muddled thinking. Journal of Workplace Learning, 15(6), 280-287.

Bierly, P. E., \& Hämäläinen, T. (1995). Organizational learning and strategy, Scandinavian Journal of Management, 11(3), 209-224.

Bierly, P., E., Kessler, E., H., \& Christensen, E., W. (2000). Organizational learning, knowledge and wisdom, Journal of Organizational Change Management, 13(6), 595-618.

Bovens, M., Schillemans, T., \& 't Hart, P. (2008). Does public accountability work? An assessment tool. Public Administration, 86(1), 225-242.

Brown, M. M., \& Brudney, J. L. (2003). Learning organizations in the public sector? A study of police agencies employing information and technology to advance knowledge. Public Administration Review, 63(1), 30-43.

Bustinza, O., F., Molina L. M. \& Arias-Aranda, D. (2010). Organizational learning and performance: Relationship between the dynamic and the operational capabilities of the firm. African Journal of Business Management, 4(18), 4067-4078.

Cacciattolo, K. (2015). Organisational politics: The positive and negative side. European Scientific Journal, 11(1), 1857-7881.

Chan, C. C. A., \& Scott-Ladd, B. (2004). Organisational learning: Some considerations for human resource practitioners, Asia Pacific Journal of Human Resources, 42(3), 336.

Chanal, V. (2004). Innovation management and organizational learning: a discursive approach, European Journal of Innovation Management, 7(1), 56-64.

Chen, L., Zheng, W., Yang, B., \& Bai, S. (2016). Transformational leadership, social capital and organizational innovation. Leadership \& Organization Development Journal, 37(7), 843-859.

Choo, C. W. (2001). The knowing organization as learning organization, Education + Training, 43(4/5), 197-205.

Choo, C., W., \& Neto, R., C., D, A. (2010). Beyond the ba: Managing enabling contexts in knowledge organizations. Journal of Knowledge Management, 14(4), 592-610.

Coopey, J., \& Burgoyne, J. (2000). Politics and organizational learning. Journal of Management Studies, 37(6), 869-885.

Coulson-Thomas, C. (2003). Transforming the company: the differing learning practices of successful and unsuccessful companies. Industrial and Commercial Training, 35(1), 5-10.

Dekker, S., \& Hansen, D. (2004). Learning under pressure: the effects of politicization on organizational learning in public bureaucracies. Journal of Public Administration Research and Theory, 14(2), 211-230.

Dent, M., Van Gestel, N., \& Teelken, C. (2007). Symposium on changing modes of governance in public sector organizations: Action and rhetoric. Public Administration, 85(1), 1-8.
Ege, T., Esen, A., \& Dizdar, Ö. A. (2017). Organisational learning and learning organisation: An integrative framework. International Journal of Management Economics and Business, 13(2), 439-460.

Espinosa, A., \& Porter, T. (2011). Sustainability, complexity and learning: Insights from complex systems approaches. The Learning Organization, 18(1), 54-72.

Espinosa, A., Harnden, R., \& Walker, J. (2007). Beyond hierarchy: a complexity management perspective. Cybernetics, 36(3), 333-347.

Fenwick, T. (2008). Understanding Relations of Individual Collective Learning in Work: A Review of Research. Management Learning, 39(3), 227-240.

Ferdinand, J. (2004). Power, politics and state intervention in organizational learning. Management Learning, 35(4), 435-450.

Friesl, M., Sackmann, S., A., \& Kremser, S. (2011). Knowledge sharing in new organizational entities: The impact of hierarchy, organizational context, micro-politics and suspicion, Cross Cultural Management: An International Journal, 18(1), 71-86.

Garavan, T., N., \& McCarthy, A. (2008). Collective learning processes and human resource development. Advances in Developing Human Resources, 10(4), 451-471.

Garcia-Morales, V. J., Matias-Reche, F., \& Hurtado-Torres, N. (2008) Influence of transformational leadership on organizational innovation and performance depending on the level of organizational learning in the pharmaceutical sector, Journal of Organizational Change Management, 21(2), 188-212.

Ghili, S., Nazarian, S., Tavana, M., Keyvanshokouhi, S., Isaai, M., T. (2013). A Complex Systems Paradox of Organizational Learning and Knowledge Management. International Journal of Knowledge-Based Organizations, 3(3), 53-72.

Gilardi, F., \& Radaelli, C. M. (2012). Governance and learning. In D. Levi-Faur (Ed.), Oxford handbook of governance (pp. 155168). Oxford: Oxford University Press.

Gilson, C., Dunleavy, P., \& Tinkler, J. (2009). Organizational learning in government sector organizations: literature review. LSE Public Policy Group, London School of Economics and Political Science, London, UK.

Greiling, D., \& Halachmi, A. (2013). Accountability and organizational learning in the public sector. Public Performance \& Management Review, 36(3), 380-406.

Gummesson, E. (2006). Qualitative research in management: addressing complexity, context and persona. Management Decision, 44(2), 167-179.

Harrison, R., \& Kessels, J. (2004). Human resource development in a knowledge economy. Basingstoke, Palgrave MacMillan, UK.

Hodgkinson, M. (2002). A shared strategic vision: dream or reality? The Learning Organization, 9(2), 89-95.

Hoe, S. L. (2007). Shared vision: a development tool for organizational learning, Development and Learning in Organizations, 21(4), 12-13.

Hsiao, H. C., \& Chang, J. C. (2011). The role of organizational learning in transformational leadership and organizational innovation. Asia Pacific Education Review, 12(4), 621-631. 
Jensen, J. A., \& Rasmussen, O. (2004). An inquiry into the foundations of organizational learning and the learning organization. The Learning Organization, 11(6), 478-490.

Jerez-Gomez, P., Cespedes-Lorente, J. J., \& Valle-Cabrera, R. (2004). Training practices and organisational learning capability: Relationship and implications. Journal of European Industrial Training, 28(2-4), 234-243.

Jerez-Gomez, P., Cespedes-Lorente, J., \& Valle-Cabrera, R. (2005). Organizational learning capability: A proposal of measurement. Journal of Business Research, 58(6), 715-735.

Johannessen, J., \& Olsen, B. (2011). Aspects of a cybernetic theory of tacit knowledge and innovation. Kybernetes, 40(1/2), 141165.

Kamya, M. T. (2012). Organizational learning and market performance: The interactive effect of market orientation. Journal of Economics and International Finance, 4(10), 226-235.

Keep, E. (2015). Corporate training strategies: the vital component? In: New Perspectives on Human Resource Management, ed. by Storey, John, 109-125. Routledge, New York.

Kluge, A., \& Schilling, J. (2003). Organizational learning and learning organizations. The Psychologist Manager-Journal, 6 , 31-50.

Kolodinsky, R., W., \& Bierly, P., E. (2013). Understanding the elements and outcomes of executive wisdom: A strategic approach. Journal of Management $\mathcal{E}$ Organisation, 19, 1-24.

Kurland, H., Peretz, H., \& Hertz-Lazarowitz, R. (2010). Leadership style and organizational learning: the mediate effect of school vision. Journal of Educational Administration, $48(1), 7-30$.

Lawrence, T. B., Mauws, M. K., Dyck, B., \& Kleysen, R. F. (2005). The politics of organizational learning: Integrating power into the 4I framework. Academy of Management Review, 30, 180-191.

LeBrasseur, R., Whissell, R., \& Ojha, A. (2002). Organisational learning, transformational leadership and implementation of continuous quality improvement in Canadian hospitals, Australian Journal of Management, 27(2), 141-252.

Levitt, B., \& March, J. G. (1988). Organizational Learning, Annual Review of Sociology 14, 319-340.

Liao, S., Chen, C., Hu, D., Chung, Y., \& Liu, C. (2017). Assessing the influence of leadership style, organizational learning and organizational innovation. Leadership $\mathcal{E}$ Organization Development Journal, 38(5), 590-609.

Lim, D., H., \& Morris, M., L. (2006). Influence of trainee characteristics, instructional satisfaction, and organizational climate on perceived learning and training transfer. Human Resource Development Quarterly, 17(1), 85-115.

Maden, C. (2012). Transforming public organizations into learning organizations: a conceptual model. Public Organization Review, 12(1), 71-84.

Michalak, J. M. (2010). Cultural catalysts and barriers of organizational change management: A preliminary overview. Journal of Intercultural Management, 2(2), 26-36.

Mirkamali, S., M., Thani, F., N., \& Alami, F. (2011). Examining the role of transformational leadership and job satisfaction in the organizational learning of an automotive manufacturing company. Social and Behavioural Sciences, 29, 139-148.
Moon, H., \& Lee, C. (2015). Strategic learning capability: Through the lens of environmental jolts, European Journal of Training and Development, 39(7), 628-640.

Mouritsen, J., Thorbjørnsen, Bukh, P., N., \& Johansen, M., R. (2004). Intellectual capital and new public management: Reintroducing enterprise, The Learning Organization, 11(4/5), 380-392.

Nonaka, I., \& Takeuchi, H. (1995). The Knowledge-Creating Company. Oxford University Press, New York, USA.

Nonaka. I., \& von Krogh, G. (2009). Tacit knowledge and knowledge conversion: Controversy and advancement in organizational knowledge creation theory. Organization Science, 20(3), 635-652.

Ntseane, P. G. (2009). The ethics of the researcher-subject relationship. In D. M. Mertens \& P. E. Ginsberg (Eds.) The handbook of social research ethics (pp 295- 169-307). Thousand Oaks, CA: Sage Publications.

Popova-Nowak, I., V., \& Cseh, M (2015). The meaning of organizational learning: A meta-paradigm perspective. Human Resource Development Review, 14(3), 299-331.

Powell, R. R. (1997). Basic Research Methods for Librarians, (3rd Ed), Greenwood Publishing Group.

Punch, M. (1994). Politics and ethics in qualitative research. In N.K. Denzin \& Y.S. Lincoln (Eds.), Handbook of qualitative research. Newbery Park, CA: Sage.

Putz, D., Schilling, J., Kluge, A., \& Stangenberg, C. (2012). Measuring organizational learning from errors: Development and validation of an integrated model and questionnaire. Management Learning, 44(5) 511-536.

Rashman, L., Withers, E., \& Hartley, J. (2009). Organizational learning and knowledge in public service organizations: a systematic review of the literature. International Journal of Management Reviews, 11(4), 463-494.

Robinson, O. C. (2014). Sampling in interview-based qualitative research: A theoretical and practical guide. Qualitative Research in Psychology, 11(1), 25-41.

Sánchez, J. Á. L., Vijande, M. L. S., \& Gutiérrez, J. A. T. (2010). Organisational learning and value creation in business markets. European Journal of Marketing, 44(11/12), 1612-1641.

Schechter, C., \& Atarchi, L. (2014). The meaning and measure of organizational learning mechanisms in secondary schools. Educational Administration Quarterly, 50(4), 577-609.

Schofield, J., \& Sausman, C. (2004). Symposium on implementing public policy: learning from theory and practice: introduction. Public Administration, 82(2), 235-248.

Seidman, I. (2013). Interviewing as qualitative research: A guide for researchers in education and the social sciences (4th ed.). New York, NY: Teachers College Press.

Senge, P., Kleiner, A., Roberts, C., Ross, R. B., \& Smith, B. J. (1999). The Fifth Discipline Field book, Nicholas Brearley Publishing, London.

Silins, H. C., Mulford, W. R., \& Zarins, S. (2002). Organizational learning and school change. Educational Administration Quarterly, 38(5), 613-642.

Slocum, J. W., McGill, M., \& Lei, D. T. (1994). The new learning strategy: Anytime, anything, anywhere, Organizational Dynamics, 23(2), 33-47. 
Snowden, D. (2005). Strategy in the context of uncertainty. Handbook of Business Strategy, 6(1), 47-54.

Tahrima, S., \& Jaegal, D. (2012). Challenges for government innovation in Bangladesh. The Korean Journal of Policy Studies, 27(2), 143-173.

Ter Horst, H., Mulder, M., Sambrook, S., Scheerens, J., Stewart, J. \& Tjepkema, S. (eds.) (2003). HRD and learning organisations in Europe. Routledge, London.

Tian, M., Deng, P., Zhang, Y., \& Salmador, M. P. (2018). How does culture influence innovation? A systematic literature review. Management Decision, https:/ / doi.org/10.1108/MD-05-20170462

Tynjala, P. (2008). Perspectives into learning at the workplace. Educational Research Review, 3, 130-154.

Voronov, M. (2008). Toward a practice perspective on strategic organizational learning, The Learning Organization, 15(2), 195221.
Wang, G. G., Lamond, D., \& Worm, V. (2015). “It's the context all the way down!": An institutional theory perspective on Chinese HRM research. Journal of Chinese Human Resource Management, 6(1), 2-13.

Werner, J., M., \& DeSimone, R., L. (2012). Human Resource Development. South-western, Mason, $\mathrm{OH}$.

Willem, A., \& Buelens, M. (2009). Knowledge sharing in inter-unit cooperative episodes: The impact of organizational structure dimensions. International Journal of Information Management, 29, 151-160.

Yeo, R. K. (2007a). Change interventions to organizational learning: Bravo to leaders as unifying agents. The Learning Organization, 14(6), 524-552.

Yeo, R. K. (2007b). Organizational learning in representative Singapore public organizations. The International Journal of Public Sector Management, 20(5) 345-365.

$--0--$ 
How to Cite: Ahsan, M. (2018). Organizational Learning as a Strategic Choice in Public Sector Organization: Changing Cultural Attributes in a State Owned Agricultural Bank of Bangladesh. American Journal of Trade and Policy, 5(3), 113-120.

\section{SOCIAL SCIENCE RESEARCH NETWORK \\ 2171 Monroe Avenue, Suite 203, Rochester, NY 14618, USA http://www.ssrn.com/en/}

SSRN Link: http://www.ssrn.com/link/American-Journal-Trade-Policy.html 